\title{
Designing model of the music art training for teacher of art and culture based on active learning
}

\author{
Iswandi $^{1}$, Yasri $^{2}$, Nurhizrah Gistituati ${ }^{3}$, Ardipal $^{4}$ \\ 1234 Universitas Negeri Padang, Padang-Indonesia, (iswandi_utha@yahoo.com)
}

\begin{abstract}
This research motivated by the problems faced by teachers of art and culture subjects of Senior High School in the Province of West Sumatra namely the low results of Teacher Competency Test with an average score of 60 in particular the field art of music. The purpose of this model design is to develop a model of music art training that is valid, practical, and effective. Research method used is Research and Development with ADDIE procedures. The sample is determined by area probability sampling technique with the number of respondents 34 teachers of arts and culture subjects. The results concluded that the average of the ability of teachers 58.75. The developed model design consists of: (1) preparation stage (training contract, ability analysis, and group division); (2) learning stages (finding concepts/theories, discussions, group demonstrations, peer feedback, training with instructor's guidance, joint demonstrations); (3) evaluation stage through observation test.
\end{abstract}

Keywords: design, model, training, art of music

\section{Introduction}

Teachers are the main and decisive factors in the implementation of education. The existence of a teacher today cannot simply be replaced by any technology and media. The important functions of teachers in the education of course teachers have adequate qualifications and competence. Speaking about the qualifications of teachers, the government set up Ministerial Regulation No. 16 Year 2007 on the Standard Qualification and Teacher Competency Standards. It is stated that "SMA/MA Teachers or other forms equivalent, must have education qualification at minimum diploma four (D-IV) or Bachelor (S1) study program in accordance with the subjects taught and obtained from accredited study programs.

Teacher competence is the ability to perform the tasks and functions, and the ability to integrate knowledge, skills, attitudes, personal values, and the ability to build knowledge and skills based on experience and lessons. Law No. 14 Year 2005 on Teachers and Lecturers Act, in Article 10, paragraph (1) states that "The competence of teachers includes pedagogical competence, personal competence, social competence, and professional competence acquired through professional education"

Talking about the teachers' qualifications and competence especially professional competence, of course it is related to the subjects that will be taught. In connection with the subject of art and culture in Senior High School and vocational schools, based on curriculum 2013, it consists of four fields of 
arts, namely drama, dance, music, and fine art. In order that arts and culture for the learning process can be implemented properly and targets are achieved as curriculum subjects, of course teachers must master all four branches of the arts. The current issue is that the teachers of art and culture in vocational education have educational background only in one branch of art that is drama, dance, music, or fine art. None of subject teachers of art and culture have a background of more than one art. Besides that based on the data I got from several districts/cities under Department of Education in West Sumatra province, it is shown that the results of Teacher Competency Test of subject of arts and culture in 2015 according to the study is still relatively low with the average value of 60 .

Preliminary study results were conducted through tests with five groups of material indicators, namely: (1) knowledge of musical notation; (2) vocal technique; (3) composing vocal music, (4) show management; and (5) listening to music, indicating that the average score for the vocal technique group is 58.82 with very low category and the group composed vocal music with an average grade of 56.24 with very low category, meanwhile the average score for musical knowledge group notation is 78.04 with high category, music performance management group average score is 81.52 with high category, and listening to music with average value of 82.48 with high category. The existing conditions show that the material group on vocal technique and composing vocal music is in very low category. Based on this, the authors conclude that to improve the competence of teachers of art and cultural subjects in the field of music art, it needs to develop a model of musical art training so that the existing problems can be solved, especially in the group of vocal technique material and composing songs. Furthermore, with the increased ability of the art of music arts subjects and cultural arts, the process of art and cultural arts in the field of high school can be improved.

In order to find the solution of the problems in the background above, the authors formulate the problem in general as "How is the model of musical art training for high school art and culture teachers developed? Meanwhile, in this paper the focus of the problem that the authors formulated is how the design of the musical art training model will be developed for teacher of art and culture subjects of Senior High School.

The education of art and culture is a lesson given to students from elementary school to high school. The education of art and culture always presents in the school curriculum, because art is part of human needs. Cultural art education is very necessary for children in daily life. Related to this matter Diknas (2004: 3) explains "The function and purpose of education of art and culture is to grow the attitude of tolerance, democracy, and civilization, and be able to live in harmony in plural society, develop intellectual imaginative ability, expressing through art, develop sensitivity of taste, and able to apply technology in creating and in exhibiting and performing artwork.

The education of music art aims at giving the learners the opportunity to express, appreciate, be creative, form harmony, and create beauty. The art of music is an art branch that uses music as a means to express the expression of its maker. Music is an art that uses sounds/sounds arranged in such a way that it contains rhythm, song, and harmony. Vocals as a medium to express music need to be trained well in order to have the values of quality beauty. With regard to the education of music art, a teacher is certainly responsible for the formation of behavioral changes in students according to the purpose of music education. One must know well the methods and techniques to teach music according to the curriculum and have the skills to practice it. Yilmaz, (2012: 3037) explains "In other words, one must not be a competent musician, too. Within this framework, he / she must have specific qualities in order to be able to carry out his/her duties in a successful way. This obligation makes music teacher training necessary.

The learning process of art and culture will run well if the teacher masters the material in theory and practice. To improve the competence of teachers, it needs to do effective training both related to the skills of playing music and singing (vocals). Training is an effort to improve the knowledge, attitude, and skills of organization members so that the performance of members of the organization 
can increase. Bernardin and Russell (1998: 172), also stated "Training is defined as any attempt to improve employee performance on a currently held job or one related to it. This usually means changes in specific knowledges, skills, attitudes, or behaviors. To be effective, training should involve a learning experience, be a planned organizational activity, and be designed in response to identified needs."

Furthermore Noe (2010: 351) states, "Training is a planned effort by an educational institution to facilitate the learning of the competencies associated with the work, which includes knowledge, skills, attitudes and behaviors". Vocal training is one of the efforts to improve the art of music of teachers. Helvaci ( 2014 : 3419) states (1) Knows the posture and body relaxation position for vocal training; (2) Knows the purpose of vocal training; (3) Knows the names of the voice production organs; (4) Knows the anatomy of the voice production organs in general; (5) Knows the correct breathing technique; (6) Applies the correct breathing technique in long and short exercises; (7) Applies the correct voice production technique in long and short exercises; (8) Knows the correct pronunciation in singing,

The conclusion of the above description is that the art of music as part of the subjects of art and culture needs to be given to the learners equivalent to other subjects. Teachers as a major component in the learning of art and culture need to have the ability in art and culture including music art both theoretically and practice. To increase the professional competence of culture and art teachers, especially music art, it is important to hold music art training.

\section{Method}

This research uses Research and Development (R \& D) method which is focused on developing a product that departs from research result about competence of teacher of art and culture subjects at High Schools. According to Borg and Gall (1989: 624), research and development is a process used to develop and validate a product. The development procedure or the steps implemented in the development of this model is Analyze, Design, Development, Implementation, and Evaluation (ADDIE).

Design is the second stage after doing the analysis. The design process undertaken is based on the results of the analysis of the professional competence of art and cultural subjects teachers, the foundations of learning theories, theories of model development, and the feasibility of its implementation. The next step is to conduct Focus Group Discussion with music practitioners, teachers of art and culture, and experts to get input and suggestions on the initial design. Expert validation involving experts is also done to gain recognition that the design is worth theoretically, substance, or methodological to be tested.

The instrument used in this initial validation test is the validation sheet for the expert. Validated components of language use, developed model structure, training materials, questioners, observation guides and interview guides. Each expert is asked to provide suggestions and feedback on the design model to be developed. The results of this validation are very helpful for the authors in revising the design and become the basis for creating hypothetical models that will be developed in the next stage.

Results

Based on the results of a survey conducted by using tests on 34 art and culture teachers in the field of music art in 14 Senior high schools in West Sumatera Province, the authors obtained data about the average score for five groups of test materials, namely: knowledge of musical notation, vocal technique, composing vocal music, show management, and listening to music as follows: 


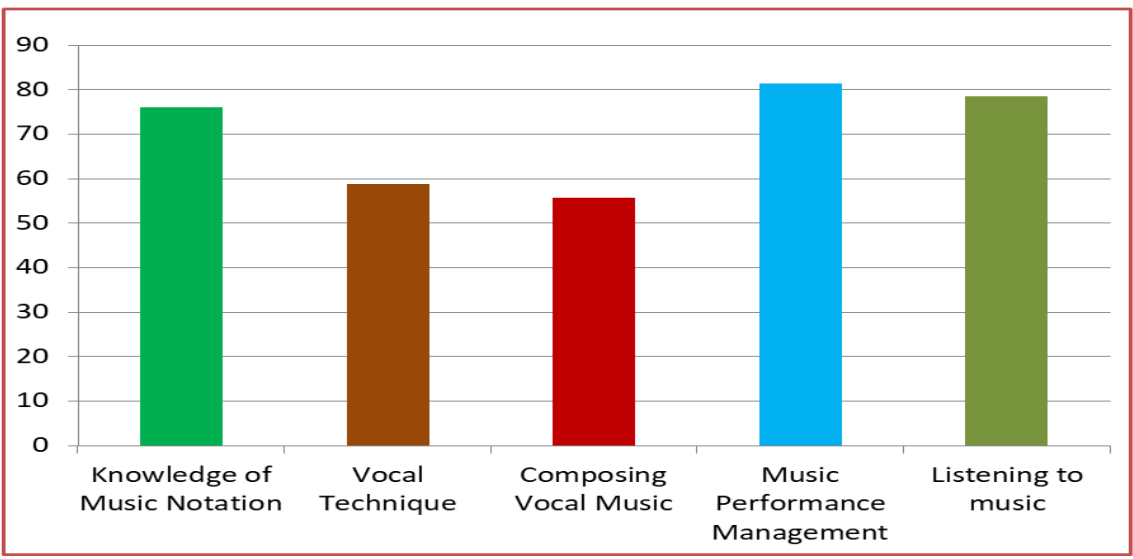

Figure 1. Test Average Value of Art And Culture Teacher's Ability in the Field of Musical Art

Figure 1 illustrates that the average score of teachers' ability for knowledge of musical notation, musical performance management, and listening to music is above 75 with high category, while for knowledge of vocal technique is 58.82 and composing vocal music is 55.63 or is under 60 with very low category. The description of this condition is concluded that the ability of teachers in the field of music art for vocal engineering material and composing vocal music needs to be improved through training.

Surveys were also conducted through observations and interviews of teachers, music lecturers and music practitioners about the training of musical arts especially vocal techniques and composing the usual vocal music. Based on observations and interviews, the authors found the factual model of musical art training as follows:

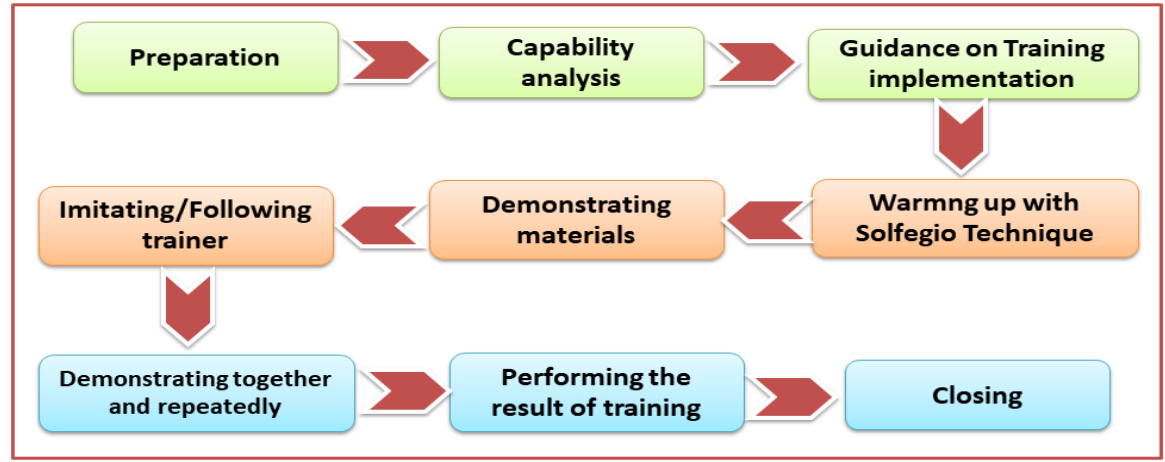

Figure 2. Factual Model of Music Art Training

The musical art training carried out does not illustrate the difference between training for teachers and training for students. Because in the context of age there are differences, of course the implementation of learning / training should also have differences. Furthermore, in the existing training, trainees imitate the trainer more or not active, Speaking of adult learning is certainly closely related to the theory of learning andragogy. Knowles (1979) defines andragogy as art and science in helping learners (adults) to learn (the science and arts of helping adults learn).

Responding to the low ability of teachers about vocal techniques and composing vocal music as well as the factual model of musical art training, the authors deem it necessary to design an active learning-based model of musical art training for teachers. Active-learning musical art-based training model is a training model designed to enable trainees to be more active from finding the concepts/theories to evaluating performance. Here is the design of active learning music art training model in Figure 3: 


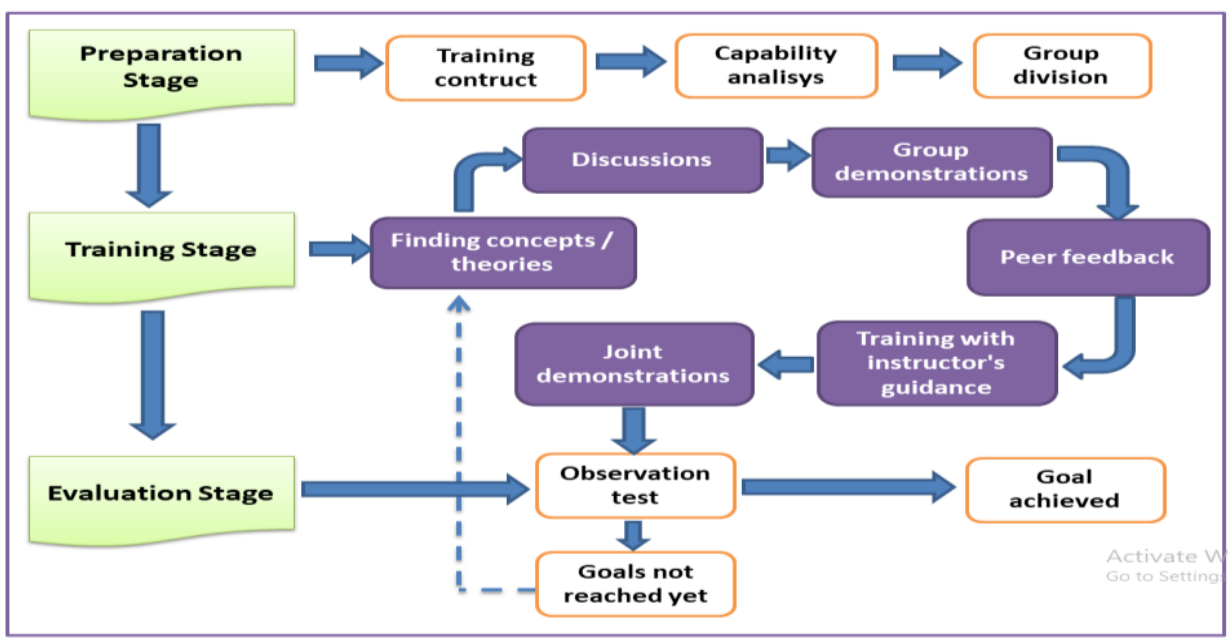

Figure 3. Initial Design of Music Art Training Based on Active Learning

Active-learning music instruction based on Active Learning procedure consists of three stage: preparation, implementation, and evaluation. The three stage are done in sequence and should be followed by all art training participants.

The preparation stage is the first step that aims at providing an understanding for the trainees about the training process to be followed. This section describes the mechanisms of music art training activities (training contracts) and skill analysis of trainees. The training contract aims at making commitments and equalizing the perceptions among the trainees as well as explaining the musical art training procedure that will be implemented.

Analysis of participants' ability in music art is done with pre-test (writing test/singing practice) to know the initial ability of each trainee and also to map the ability of each participant. The next activity is the division of learning groups to create an active learning atmosphere by placing high, moderate, and low-ability participants in each group.

The implementation stage consists of six activities, namely: (1) determining the concept/theory through books or internet; (2) conducting group discussions; (3) demonstrating the discussion material of each group; (4) providing input / suggestion to the group that gives presentation ; (5) training with the instructor's guidance to correct the weaknesses of the participants; and (6) demonstrating material together and repeatedly. In the training implementation stage, trainees are required to be really active, while the instructor functions only as a director and facilitator. Instructors are expected to improve things that the trainees do not understand and master.

The last stage in the training of music art is the evaluation of the material that has been learned by the trainees. Evaluation is done in the form of observation test/practice test equipped with measured assessment indicators. Evaluation aims at seeing whether the participants have mastered the training materials in the form of music practice or not. If the results of the evaluation have shown that the ability of the participants has increased, then it can be said that the objectives of the training has been achieved. But if the ability of trainees has not increased yet, it is necessary to re-train the participants in order that their skill really increases.

The design of this music art training model has its own characteristic that has not existed yet in other music art training model namely active learning base, meaning that the teacher as the trainee becomes the learning/training center with the instructor's guidance, starting from getting the material (concept/theory) training to demonstrating the materials together. Meanwhile, when compared with other training models, the design of this model also has the same pattern of implementation that is 
planning, implementation, and evaluation. Rosiani, Martono, Kardoyo (2014: 72) point out, "Three stages of teacher's competency-building training develop classroom action research-based learning that is first, training planning (needs analysis, objective formulation, and designing training activities), second, implementation (opening, core, and closing), third on the evaluation of the training, evaluation of reactions, learning, and products are carried out". Susatya, Edhy (2013) also designed an effective training model design, called Open Design consisting of: 1) the planning stage; 2) implementation stage; and 3) evaluation stage. What distinguishes this training with others is the syntax (the stages in carrying out the training itself).

\section{Conclusion}

Design is one of the stages in developing a model of music art training for art and culture teachers. The design process is based on the results of the analysis of the professional competence of art and culture teachers, the foundations of learning theories, theories of model development, and the feasibility of its implementation. The initial design that will be developed are: (1) preparation stage in the form of training contract submission, ability analysis, and group division. (2) the learning / training stage consisting of defining concepts / theories, conducting group discussions, group demonstrations, giving / receiving fellow input, training with instructor guidance, and demonstrating collectively and repeatedly. (3) evaluation stage in the form of observation test / practice. To gain recognition that this design is worth theoretically, substantially, or methodologically to be tested, expert validation is done which involves experts.

\section{References}

Borg, W. R. and Gall, M. D. (1983). Educational research: An introduction. New York and London: Longman.

Helvac1, Ayhan. (2014). Voice training practices "Uludağ University sample" in universities providing theatre training in Turkey. Procedia - Social and behavioral sciences Vol. 116.

Ibrahim A. A. (2016). The efficiency of a selective training program on the development of some social skills of Saudi students with autism. International Education Studies; Vol. 9, No. 5; 2016 ISSN 19139020 E-ISSN 1913-9039

Noe, R. A. (2010). Manajemen sumber daya manusia mencapai keunggulan bersaing. NY: McGraw-Hill

Rosiani Dewi, Martono, S., Kardoyo. (2014). Pengembangan model pelatihan peningkatan kompetensi guru mengembangkan pembelajaran berbasis penelitian tindakan kelas. Jurnal Penelitian Tindakan Sekolah dan Kepengawasan, Vol. 1, No. 2, Oktober 2014. ISSN 2355-9683.

Susatya, Edhy (2013). Development of training model for teachers of arts and culture at vocational senior secondary school. Journal education and Culture, Vol. 19.

Undang-Undang RI Nomor 14 Tahun 2005 Tentang Guru dan Dosen

Wahyudi. (2010). Standar kompetensi profesional guru. Jurnal Pendidikan Sosiologi dan Humaniora, Vol. 1. No. 2. Oktober 2010, p. 107-119. http://jurnal.untan.ac.id /index.php/JPSH/article/download/385/388.

Yilmaz, Nilufer. (2012). A historical view of music teacher training in turkey from the past to the present. Procedia - Social and Behavioral Sciences Vol. 46. 